\title{
Kualitas Telur Itik setelah Perendaman dengan Ekstrak Daun Salam (Syzygium polyantha) dan disimpan pada Suhu $4^{\circ} \mathrm{C}$
}

\section{Quality Duck Egg After Submersion with Bay Leaf Extract (Syzygium polyantha) and Stored at $4^{\circ} \mathrm{C}$}

\author{
Zuni Novika $^{1}$, M. Anwar Djaelani ${ }^{2}$, S. M. Mardiati ${ }^{2}$ \\ ${ }^{1)}$ Program Studi Biologi, Departemen Biologi, Fakultas Sains dan Matematika, Universitas Diponegoro \\ ${ }^{2)}$ Departemen Biologi, Fakultas Sains dan Matematika, Universitas Diponegoro \\ Jl. Prof. Soedarto, SH, Tembalang, Semarang \\ Email: zuni.novika@yahoo.com
}

Diterima 5 Januari 2017 / Disetujui 27 Agustus 2017

\begin{abstract}
ABSTRAK
Telur mudah mengalami penurunan kualitas yang disebabkan oleh penguapan air dan $\mathrm{CO}_{2}$ sehingga perlu dilakukan pengawetan untuk mempertahankan kualitas telur. Tujuan penelitian ini adalah untuk mengetahui pengaruh perendaman dengan ekstrak daun salam dan penyimpanan pada suhu $4^{\circ} \mathrm{C}$ terhadap kualitas telur itik. Penelitian dilakukan dengan Rancangan Acak Lengkap (RAL), data dianalisis menggunakan uji Anova dan uji Duncan dengan taraf signifikansi 5\%. Telur yang digunakan sebanyak 45 butir, dibagi dalam 9 perlakuan dan 5 kali ulangan. P0 (kontrol), P1 dan P2 (Telur dicuci, direndam ekstrak daun salam, disimpan 14 dan 28 hari pada suhu $4^{\circ} \mathrm{C}$ ), P3 dan P4 (Telur dicuci, tidak direndam ekstrak daun salam, disimpan 14 dan 28 hari pada suhu $4^{\circ} \mathrm{C}$ ), P5 dan P6 (Telur tidak dicuci, direndam ekstrak daun salam, disimpan 14 dan 28 hari pada suhu $4^{\circ} \mathrm{C}$ ), P7 dan P8 (Telur tidak dicuci, tidak direndam ekstrak daun salam, disimpan 14 dan 28 hari pada suhu $4^{\circ} \mathrm{C}$ ). Variabel yang diamati pada penelitian ini adalah Indeks Kuning Telur (IKT), kadar lemak telur, dan susut bobot telur. Kesimpulan dari penelitian ini adalah perendaman telur dengan ekstrak daun salam tidak mampu mempertahankan kualitas telur itik.
\end{abstract}

Kata kunci : Syzygium polyantha, indeks kuning telur, lemak telur, susut bobot

\begin{abstract}
Egg quality was easy to decrease because of evaporation of water and carbon dioxide. Because of that, eeg needs preservation to preserve its quality. The purpose of this study was to determine the effect of submersion in bay leaves extract and stored at $4^{\circ} \mathrm{C}$ towards the duck egg's quality. This study, which used data with completely randomized design (CRD) were analyzed with Anova test and further tested by Duncan test with a significance level of 5\%. The eggs used were 45 which were divided into 9 treatments and 5 repetitions. P0 (control), P1 and P2 (Eggs were washed, submerged in bay leaves extract, kept for 14 and 28 days at $4^{\circ} \mathrm{C}$ ), P3 and P4 (Eggs were washed, not submerged in bay leaves extract, kept for 14 and 28 days at $4^{\circ} \mathrm{C}$ ), P5 and P6 (eggs were not washed, submerged in bay leaves extract, kept for 14 and 28 days at $4^{\circ} \mathrm{C}$ ), P7 and P8 (eggs were not washed, not submerged in bay leaves extract, kept for 14 and 28 days at $4^{\circ} \mathrm{C}$ ). The Variables observed in this study were the yolk index, the egg's fat, and the weight decrease. The conclusion of this study was the egg submersion in the bay leaves extract could not preserve the duck egg's quality.
\end{abstract}

Keywords: Syzygium polyantha, yolk index, egg's fat, weight decrease

\section{PENDAHULUAN}

Telur merupakan salah satu produk hewani yang berasal dari ternak unggas dan telah dikenal sebagai bahan pangan sumber protein yang bermutu tinggi. Telur sebagai bahan pangan mempunyai banyak kelebihan misalnya, kandungan gizi telur yang tinggi, harganya relatif murah bila dibandingkan dengan bahan sumber protein lainnya. Telur merupakan bahan pangan yang mudah terkontaminasi mikroba baik secara langsung atau tidak langsung. Sifat telur yang 
mudah rusak dan busuk selain disebabkan oleh mikroba, juga disebabkan karena penguapan air, penguapan karbondioksida, dan aktivitas mikroba sekitar lingkungan telur (Idayanti dkk., 2009).

Upaya dalam memperpanjang daya simpan telur sehingga dapat bertahan lama salah satunya dilakukan dengan jalan pengawetan. Pengawetan yang digunakan merupakan pengawetan alami serta aman jika dikonsumsi (Rahmawati dkk., 2014). Prinsip yang dipakai pada pengawetan telur adalah pencegahan pelepasan uap air dan gas terutama $\mathrm{CO}_{2}$ dari dalam telur, serta mencegah penetrasi bakteri ke dalam telur. Ada beberapa cara yang dapat dilakukan untuk memperpanjang masa simpan telur selain membuat telur asin yaitu dengan penyamakan telur. Proses tersebut dapat dilakukan dengan cara menggunakan bahan penyamak nabati berupa tanin yang dapat diperoleh dari daun jambu biji, daun teh, kulit bawang merah, dan kulit kayu (Budisutiya dan Arisandi, 2006).

Daun salam mempunyai kandungan kimia yaitu tanin, flavonoid, dan minyak atsiri $0,05 \%$ yang terdiri dari eugenol dan sitral. Kandungan Eugenia polyantha merupakan bahan aktif yang diduga mempunyai efek farmakologis. Tanin dan flavonoid merupakan bahan aktif yang mempunyai efek anti inflamasi dan antimikroba, sedangkan minyak atsiri mempunyai efek analgesik. (Sumono dan Wulan,2009). Tanin merupakan senyawa aktif metabolit sekunder yang diketahui mempunyai khasiat yaitu sebagai astringen, (Desmiaty et al., 2008). Tanin yang berkhasiat sebagai astringen diharapkan mampu menutup pori pada kulit luar atau cangkang telur, sehingga menghambat masuknya bakteri maupun penyakit melalui pori tersebut.

Daun salam juga lebih aman dikonsumsi karena umum dipakai sebagai bumbu penyedap masakan. Berdasarkan latar belakang di atas, maka perlu dilakukan penelitian mengenai penggunaan daun salam (Syzygium polyantha) sebagai alternatif pengawetan telur itik, dengan harapan dapat mempertahankan kualitas telur dalam waktu yang lebih lama.

\section{METODE PENELITIAN}

\section{Alat dan Bahan}

Bahan yang digunakan adalah 45 butir telur itik, $2 \mathrm{~kg}$ daun salam, dan 4 liter air. Alat yang digunakan adalah timbangan digital dengan ketelitian 0,01 gram, egg tray, blender, kompor, panci, baskom, kaca bidang datar, jangka sorong, tusuk gigi, lemari es, dan alat tulis.

\section{Pengambilan Sampel}

Telur itik diambil dari peternak di Pandansari Semarang. Sampel yang digunakan yaitu telur itik berumur 1 hari, dipilih telur yang bersih dari kotoran, dan memiliki bobot yang seragam.

\section{Rancangan Percobaan}

Penelitian dilakukan dengan Rancangan Acak Lengkap (RAL), data dianalisis menggunakan uji Anova dan uji Duncan dengan taraf signifikansi 5\%. Telur yang digunakan sebanyak 45 butir, dibagi dalam 9 perlakuan dan 5 kali ulangan. P0 (kontrol), P1 dan P2 (Telur dicuci, direndam ekstrak daun salam, disimpan 14 dan 28 hari pada suhu $4^{\circ} \mathrm{C}$ ), P3 dan $\mathrm{P} 4$ (Telur dicuci, tidak direndam ekstrak daun salam, disimpan 14 dan 28 hari pada suhu $4^{\circ} \mathrm{C}$ ), P5 dan P6 (Telur tidak dicuci, direndam ekstrak daun salam, disimpan 14 dan 28 hari pada suhu $4^{\circ} \mathrm{C}$ ), P7 dan P8 (Telur tidak dicuci, tidak direndam ekstrak daun salam, disimpan 14 dan 28 hari pada suhu $4^{\circ} \mathrm{C}$ ). Variabel yang diamati adalah indeks kuning telur, kadar lemak telur, dan susut bobot telur.

\section{Pencucian Telur}

Kelompok perlakuan P1, P2, P3, dan P4 merupakan kelompok telur dengan perlakuan pencucian. Telur dicuci menggunakan air mengalir untuk menghilangkan kotoran yang menempel pada kerabang telur, setelah dibersihkan, telur ditimbang satu persatu untuk mengetahui bobot awalnya (Fibrianti dkk., 2012). 


\section{Pembuatan Ekstrak Daun Salam}

Daun salam sebanyak $2 \mathrm{~kg}$ dan 4 liter air diblender hingga menjadi larutan yang homogen. Ekstraksi daun salam dilakukan dengan metode pemanasan hingga mendidih pada suhu $100^{\circ} \mathrm{C}$ selama 30 menit (Cornelia dkk., 2005). Hasil ekstrak daun salam dianalisis kandungan taninnya secara spektrofotometri.

\section{Perendaman Telur}

Telur direndam ke dalam ekstrak daun salam sampai semua permukaan telur terendam ditiriskan dan diletakkan pada egg tray sesuai cara yang dilakukan oleh Cornelia (2014), selanjutnya telur disimpan pada suhu $4^{\circ} \mathrm{C}$. Peletakkan telur pada waktu peyimpanan dilakukan secara acak.

\section{Analisis Indeks Kuning Telur}

Perhitungan IKT diawali dengan telur dipecah secara hati-hati, kemudian diletakkan pada kaca bidang datar, kemudian diukur tinggi kuning telur dan diameter kuning telur dengan jangka sorong, kemudian dihitung Indeks Kuning Telur (IKT) menggunakan rumus menurut Indrawan dkk. (2012) :

$$
\text { IKT }=\frac{\text { Tingg Kuning Telur }(\mathrm{mm})}{\text { Diameter Kuning Telur }(\mathrm{mm})}
$$

\section{Analisis Kadar Lemak Telur}

Pengukuran kadar lemak telur diukur dengan metode ekstraksi Soxhlet dengan rumus menurut Bintanah dan Handarsari (2014) :

$$
\text { Kadar lemak } \%=\frac{\text { berat lemak }}{\text { berat sampel }} \times 100 \%
$$

\section{Analisis Susut Bobot Telur}

$\begin{array}{ccrr}\text { Telur } & \text { ditimbang } & \text { terlebih } & \text { dahulu } \\ \text { menggunakan } & \text { timbangan } & \text { digital } & \text { untuk }\end{array}$ mendapatkan bobot telur yang telah mengalami penyimpanan kemudian dibandingkan dengan data bobot telur sebelum penyimpanan. Pengukuran susut bobot telur dihitung dengan rumus menurut Jazil (2012) :
Susut bobot $=\left(\frac{\text { bobot awal-bobot akhir }}{\text { bobot awal }} \times 100 \%\right.$

\section{HASIL DAN PEMBAHASAN}

Hasil analisis data penelitian pengaruh perendaman eksrak daun salam (Syzygium polyantha) dan penyimpanan pada suhu $4^{\circ} \mathrm{C}$ terhadap Indeks Kuning Telur (IKT), lemak telur, dan susut bobot telur disajikan pada tabel 4.1. Hasil analisis pengaruh perendaman telur dengan ekstrak daun salam yang disimpan pada suhu $4^{\circ} \mathrm{C}$ dengan lama waktu penyimpanan yang berbeda terhadap Indeks Kuning Telur (IKT) menunjukkan hasil yang berbeda nyata ( $>>0,05)$. Faikoh (2014), menjelaskan bahwa Indeks Kuning Telur (IKT) adalah perbandingan tinggi kuning telur dengan garis tengah kuning telur. Telur segar mempunyai indeks kuning telur 0,33-0,50 dengan rata-rata 0,42 . Umur telur yang semakin tua/lama dapat menurunkan nilai IKT karena penambahan ukuran kuning telur akibat perpindahan air dari putih ke kuning telur. Standar untuk IKT adalah sebagai berikut : $0,22=$ rendah, $0,39=$ rata-rata, dan 0,45 $=$ tinggi.

Hasil analisis menunjukkan bahwa perlakuan $\mathrm{P} 0$ berbeda nyata dengan $\mathrm{P} 2, \mathrm{P} 4, \mathrm{P} 5, \mathrm{P} 6$, dan P7. Indeks Kuning Telur (IKT) yang didapat pada pengamatan telur hari pertama atau kontrol tergolong kualitas tinggi yaitu 0,43 dan IKT mengalami penurun pada pengamatan berikutnya. Umur telur yang semakin bertambah, maka IKT semakin menurun karena penambahan ukuran kuning telur sebagai akibat pemindahan air dari putih ke kuning telur. Hal ini menunjukkan bahwa waktu penyimpanan telur mempengaruhi nilai Indeks Kuning Telur (IKT). Tarigan dan Agustina (2016) menyatakan bahwa umur telur mempengaruhi kekuatan dan elastisitas membran vitelin yang menyebabkan kuning telur melemah. Kekuatan dan elastisitas membran vitelin dipengaruhi oleh faktor ukuran telur, temperatur penyimpanan, $\mathrm{pH}$ putih telur dan kekentalan putih telur. Cornelia dkk. (2014) menyatakan bahwa dengan bertambahnya umur telur, Indeks Kuning Telur (IKT) menurun karena penambahan ukuran diameter kuning telur sebagai akibat perpindahan 
air. Soeparno dkk. (2011) menyatakan tekanan osmotik kuning telur lebih besar dari putih telur sehingga air dari putih telur berpindah menuju kuning telur. Proses ini menyebabkan penurunan elastisitas membran vitelin dan membesarnya diameter kuning telur.

Hasil analisis Indeks Kuning Telur (IKT) menunjukkan bahwa tidak terdapat perbedaan nyata antara P0 dengan $\mathrm{P} 1$ dan $\mathrm{P} 3$, perlakuan $\mathrm{P} 2$, P6 tidak berbeda nyata dengan $\mathrm{P} 8$, perlakuan $\mathrm{P} 4$ tidak berbeda nyata dengan P8. Hal ini menunjukkan bahwa pencucian dan perendaman telur dengan ekstrak daun salam tidak berpengaruh terhadap nilai IKT. Hal ini diduga karena kurangnya kadar tanin yang digunakan untuk perendaman telur, sehingga tanin tidak mampu melapisi pori kerabang telur dengan baik. Kadar tanin yang digunakan pada penelitian ini yaitu 3,74\%. Lestari dkk. (2013) menyatakan bahwa semakin tinggi kadar tanin menunjukkan kualitas telur yang lebih bagus. Lama perendaman yang lebih lama lebih dapat mempertahankan kualitas dan daya simpan telur. Hadjrawati dkk. (2012) menyatakan bahwa kadar tanin 6,73\% mampu mempertahankan kualitas telur sampai 30 hari masa penyimpanan.

Tabel 4.1. Hasil analisis data pengaruh perendaman ekstrak daun salam terhadap Indeks Kuning Telur (IKT), Lemak Telur (LT), dan Susut Bobot Telur (SB) pada telur itik yang disimpan pada suhu $4^{\circ} \mathrm{C}$ dengan waktu penyimpanan yang berbeda.

\begin{tabular}{|c|c|c|c|c|c|c|c|c|c|}
\hline \multirow[t]{2}{*}{ Variabel } & \multicolumn{9}{|c|}{ Perlakuan } \\
\hline & P0 & P1 & P2 & P3 & P4 & P5 & P6 & P7 & P8 \\
\hline IKT & $0,43^{\mathrm{a}} \pm$ & $0,41^{\mathrm{ab}} \pm$ & $0,33^{\mathrm{c}} \pm$ & $0,41^{\mathrm{ab}} \pm$ & $0,29^{\mathrm{d}} \pm$ & $0,40^{\mathrm{b}} \pm$ & $0,33^{\mathrm{c}} \pm$ & $0,39^{\mathrm{b}} \pm$ & $0,31^{\mathrm{cd}} \pm$ \\
\hline & 0,21 & 0,01 & 0,03 & 0,00 & 0,01 & 0,02 & 0,01 & 0,01 & 0,01 \\
\hline LT (\%) & $14,02^{\mathrm{a}}$ & $13,34^{\mathrm{ab}} \pm$ & $11,13^{\mathrm{cd}} \pm$ & $13,37^{\mathrm{ab}} \pm$ & $10,62^{\mathrm{d}} \pm$ & $12,98^{\mathrm{b}} \pm$ & $11,55^{\mathrm{c}} \pm$ & $13,12^{\mathrm{b}} \pm$ & $11,24^{\mathrm{cd}}$ \\
\hline SB (\%) & $\pm 0,14$ & $\begin{array}{l}0,55 \\
0,90^{\mathrm{a}} \pm \\
0,44\end{array}$ & $\begin{array}{l}0,48 \\
2,26^{\mathrm{b}} \pm \\
0,75\end{array}$ & $\begin{array}{l}0,48 \\
0,95^{\mathrm{a}} \pm \\
0,23\end{array}$ & $\begin{array}{l}0,46 \\
2,91^{b} \pm \\
0,39\end{array}$ & $\begin{array}{l}0,47 \\
1,35^{\mathrm{a}} \pm \\
1,03\end{array}$ & $\begin{array}{l}0,80 \\
2,19^{b} \pm \\
0,25\end{array}$ & $\begin{array}{l}0,63 \\
1,28^{\mathrm{a}} \pm \\
0,53\end{array}$ & $\begin{array}{l} \pm 0,13 \\
2,61^{\mathrm{b}} \pm \\
0,27\end{array}$ \\
\hline
\end{tabular}

Keterangan: angka yang diikuti superskrip yang berbeda pada kolom yang sama menunjukkan hasil yang berbeda nyata $(\mathrm{P}<0,0$

Faktor yang mempengaruhi IKT pada penelitian ini yaitu lama penyimpanan. Yuwanta (2010) penyimpanan telur dapat menyebabkan terjadinya perpindahan air dari putih telur menuju kuning telur sebanyak $10 \mathrm{mg} /$ hari pada temperatur $10^{\circ} \mathrm{C}$. Besarnya transfer air ini tergantung dari kekentalan putih telur dan temperatur, apabila terjadi transfer air dari putih telur ke dalam kuning telur, maka kuning telur menjadi lembek sehingga indeks kuning telur menurun, membran vitelin rusak sehingga kuning telur mudah pecah, kuning telur mengandung banyak air sehingga viskositasnya menurun.

Hadjrawati dkk. (2012) menyatakan bahwa penurunan elastisitas membran vitelin yang terdapat pada kuning telur disebabkan tekanan osmotik kuning telur lebih tinggi dibandingkan dengan putih telur. Putih telur memiliki kandungan air yang lebih banyak dibandingkan dengan komponen telur lainnya.
Hasil analisis pengaruh perendaman telur dengan ekstrak daun salam yang disimpan pada suhu $4^{\circ} \mathrm{C}$ dengan lama waktu penyimpanan yang berbeda terhadap lemak telur menunjukkan hasil berbeda nyata $(\mathrm{P}<0,05)$. Hal ini dibuktikan dengan presentase kadar lemak telur yang menurun pada pengamatan berikutnya. Hasil analisis menunjukkan bahwa terdapat perbedaan nyata antara perlakuan P0 dengan P2, P4, P5, P6, P7, P8. Hasil analisis juga menunjukkan bahwa terdapat perbedaan tidak nyata antara $\mathrm{P} 0, \mathrm{P} 1$, dan $\mathrm{P}$, perlakuan P1, P3, P5, dan P7, perlakuan P2, P4, dan $\mathrm{P} 8$, perlakuan $\mathrm{P} 2, \mathrm{P} 6$, dan $\mathrm{P} 8$, sedangkan perlakuan $\mathrm{P} 4$ berbeda nyata dengan $\mathrm{P} 6$.

Hasil analisis kadar lemak telur menunjukkan bahwa perlakuan P0 berbeda nyata terhadap P2, P4, P5, P6, P7, dan P8. Perlakuan P0 memiliki kadar lemak paling tinggi dibandingkan semua perlakuan, hal ini diduga karena telur pada P0 masih berumur satu hari, sehingga kualitas telur 
masih baik dan memiliki kadar lemak yang lebih tinggi dibandingkan dengan telur yang disimpan selama 14 dan 28 hari. Perlakuan P2, P4, P5, P6, P7, P8 mempunyai kadar lemak yang lebih rendah dari P0, hal ini terjadi karena adanya penyimpanan telur selama 14 dan 28 hari sehingga menyebabkan penurunan kualitas telur. Yuwanta (2010) menyatakan bahwa lemak telur terdapat pada kuning telur yang dibungkus oleh membran vitelin yang tersusun oleh keratin dan ovomusin, membran ini memisahkan putih dan kuning telur. Penurunan kulitas telur berlangsung seiring dengan lamanya waktu penyimpanan, hal ini terjadi karena telur yang disimpan lebih lama dapat menyebabkan rusaknya membran vitelin. Kerusakan pada membran vitelin menyebabkan rusaknya kuning telur sehingga menyebabkan nilai IKT menurun dan akan berpengaruh terhadap kadar lemak telur. $\mathrm{K}$

Kadar lemak telur P0 yaitu 14,02\%, terjadi penurunan kadar lemak pada telur yang disimpan 14 hari yaitu menjadi 12,98\% - 13,34\%, kadar lemak semakin menurun pada penyimpanan 28 hari menjadi 10,62\% - 11,55\%. Hasil analisis lemak telur menunjukkan bahwa tidak terdapat perbedaan nyata antara perlakuan P0 dengan P1, $\mathrm{P} 3$, perlakuan $\mathrm{P} 4$ dengan $\mathrm{P} 2, \mathrm{P} 8$, perlakuan $\mathrm{P} 6$ dengan P2, P8. Pencucian dan perendaman telur dengan ekstrak daun salam tidak memberikan pengaruh pada kadar lemak telur. Hal ini dimungkinkan karena kurangnya kadar tanin yang digunakan untuk perendaman telur, sehingga telur tidak mampu terlapisi tanin dengan baik. Lestari dkk. (2013) menyatakan bahwa semakin tinggi kadar tanin dapat mempertahankan kualitas dan daya simpan telur. Hadjrawati dkk. (2012) menyatakan bahwa kadar tanin 6,73\% mampu mempertahankan kualitas telur sampai 30 hari masa penyimpanan.

Tujuan dari perendaman telur ke dalam ekstrak daun salam yaitu untuk melapisi pori kerabang telur dengan tanin yang terdapat pada daun salam. Tanin merupakan senyawa antibakteri yang akan bereaksi dengan protein pada kerabang telur sehingga terbentuk endapan coklat yang dapat menutup pori telur. Faktor yang mempengaruhi kadar lemak telur pada penelitian ini yaitu lama penyimpanan. Telur yang disimpan semakin lama menyebabkan membran vitelin rusak sehingga kuning telur mudah pecah dan mempengaruhi kadar lemak telur.

Hasil analisis pengaruh perendaman telur ke dalam ekstrak daun salam dan disimpan pada suhu $4^{\circ} \mathrm{C}$ dengan lama waktu penyimpanan yang berbeda terhadap susut bobot telur menunjukkan hasil yang berbeda nyata $(\mathrm{P}<0,05)$. Hal ini dibuktikan dengan presentase susut bobot telur yang meningkat pada pengamatan berikutnya. Finata. dkk (2015) menyatakan bahwa lama penyimpanan mempengaruhi susut bobot telur dan bisa menjadi salah satu faktor pendukung menurunnya kualitas telur. Telur yang disimpan semakin lama maka akan mempercepat terjadinya kerusakan telur. Jazil (2012) menyatakan semakin lama penyimpanan telur akan semakin meningkat penyusutan bobot telur.

Hasil analisis susut bobot telur menunjukkan bahwa terdapat perbedaan nyata antara perlakuan penyimpanan 14 hari (P1 berbeda nyata terhadap $\mathrm{P} 3)$ dan penyimpanan 28 hari (P2 berbeda nyata terhadap P4). Terdapat perbedaan tidak nyata antara perlakuan P5, P7 dengan P1 dan P3, serta perlakuan P6, P8 dengan P2 dan P4. Perlakuan P1 berbeda nyata dengan P3, dan perlakuan P2 berbeda nyata dengan $\mathrm{P} 4$. Hal ini menunjukkan bahwa pencucian telur tanpa diikuti perendaman telur ke dalam ekstrak daun salam dapat mempercepat laju penyusutan bobot telur. Pencucian telur dapat menyebabkan rusaknya kutikula. Saraswati (2015) menyebutkan bahwa kutikula merupakan lapisan paling luar yang menyelubungi seluruh permukaan kerabang telur. Kerusakan pada kutikula akan mempermudah terjadinya penguapan gas dan penetrasi bakteri ke dalam telur.

Fibrianti (2012) menjelaskan pencucian telur mempercepat penurunan kualitas telur karena pada saat telur dibersihkan pori kulit telur terbuka dan terdapat selaput kutikula yang melapisi kulit telur ikut hilang. Hilangnya selaput kutikula maka mikroorganisme masuk dengan mudahnya ke dalam telur., sebaliknya dapat merangsang terjadinya kontaminasi Salmonella. Pencucian telur sebaiknya dilakukan dengan air hangat pada suhu $77^{\circ} \mathrm{C}$ karena dapat mengurangi jumlah Salmonella. Gole et al. (2014) menjelaskan bahwa 
tingkat penetrasi Salmonella ke dalam telur yang dicuci lebih tinggi dibandingkan dengan telur yang tidak dicuci. Pencucian telur akan merusak lapisan kutika sehingga bakteri akan mudah masuk ke dalam telur dan dapat mengakibatkan kebusukan telur.

Penyusutan bobot telur yang terjadi selama penyimpanan disebabkan oleh penguapan air dan pelepasan gas $\mathrm{CO}_{2}$ dari dalam isi telur melalui pori kerabang. Penguapan dan pelepasan gas ini terjadi secara terus menerus selama penyimpanan sehingga semakin lama telur disimpan berat telur akan semakin berkurang. Eke et al. (2013) menjelaskan bahwa terdapat penyusutan bobot telur secara nyata selama 4 minggu penyimpanan. Faktor yang mempengaruhi penyusutan bobot telur yaitu lama penyimpanan telur. Lama penyimpanan telur dapat menurunkan bobot telur karena terjadi penguapan air dan pelepasan $\mathrm{CO}_{2}$ dari dalam telur melalui pori kerabang sehingga semakin lama telur disimpan bobot telur akan semakin berkurang.

Hasil analisis susut bobot telur menunjukkan bahwa tidak terdapat perbedaan nyata antara perlakuan penyimpanan 14 hari (P5, P7 tidak berbeda nyata terhadap P1, P3). Hasil yang sama juga ditunjukkan pada perlakuan penyimpanan 28 hari (P6, P8 tidak berbeda nyata terhadap P2, P4). Hal ini menunjukkan bahwa pencucian dan perendaman telur dengan ekstrak daun salam tidak berpengaruh terhadap susut bobot telur. Hal ini dimungkinkan karena kurangnya kadar tanin yang digunakan untuk perendaman telur, sehingga tanin tidak mampu melapisi pori kerabang dengan baik. Lestari dkk. (2013) menyatakan bahwa semakin tinggi kadar tanin dan semakin lama waktu perendaman telur dapat mempertahankan kualitas telur. Hadjrawati dkk. (2012) menyatakan bahwa kadar tanin 6,73\% mampu mempertahankan kualitas telur sampai 30 hari masa penyimpanan.

Tujuan dari perendaman telur ke dalam eksrak daun salam yaitu agar pori kerabang telur terlapisi oleh tanin sehingga akan mengurangi terjadinya penguapan $\mathrm{CO}_{2}$ dari dalam telur. Aswar (2011) menjelaskan bahwa proses pelapisan dengan bahan penyamak yang baik adalah memiliki laju penyusutan yang lebih kecil dibandingkan dengan telur tanpa bahan penyamak.
Faktor yang mempengaruhi susut bobot telur pada penelitian ini yaitu lama penyimpanan. Yuwanta (2010) menyatakan penurunan bobot telur dipengaruhi oleh suhu penyimpanan, kelembaban relatif dan porositas kerabang telur. Suhu penyimpanan pada penelitian ini adalah $4^{\circ} \mathrm{C}$. Lubis dkk. (2012), menjelaskan bahwa penyimpanan pada suhu $4^{\circ} \mathrm{C}$ dapat memperlambat aktivitas metabolisme, menghambat pertumbuhan bakteri, dan hilangnya kadar air dari telur, serta dapat mencegah pertumbuhan mikroorganisme penyebab kerusakan atau kebusukan telur. Akyurek and Aylin (2009) menjelaskan bahwa telur dapat dipertahankan mutunya dalam waktu yang lebih lama bila disimpan di dalam ruangan dingin. Chung and Kyung (2014) menjelaskan bahwa telur yang disimpan pada suhu $4^{\circ} \mathrm{C}$ memiliki susut bobot yang lebih rendah dibanding dengan telur yang disimpan pada suhu $25^{\circ} \mathrm{C}$. Penyusutan bobot telur yang telah disimpan 14 hari pada suhu $4^{\circ} \mathrm{C}$ adalah $0,97 \mathrm{~g}$ dan $1,71 \mathrm{~g}$ pada suhu $25^{\circ} \mathrm{C}$. Penyusutan bobot meningkat pada telur yang disimpan selama 28 hari pada suhu $4^{\circ} \mathrm{C}$ yaitu sebesar $1,86 \mathrm{~g}$ dan $3,48 \mathrm{~g}$ pada suhu $25^{\circ} \mathrm{C}$. Badan Standarisasi Nasional (2008) menjelaskan bahwa telur yang disimpan pada suhu $4-7^{\circ} \mathrm{C}$ dengan kelembaban $60 \%-70 \%$ dapat lebih lama bertahan sampai penyimpanan 30 hari. Akyurek and Okur (2009) menjelaskan bahwa suhu dan lama penyimpanan mempengaruhi susut bobot telur. Penyimpanan suhu rendah memiliki susut bobot yang lebih kecil dibanding dengan penyimpanan pada suhu ruang. Telur yang disimpan selama 7 hari pada suhu $4^{\circ} \mathrm{C}$ memiliki penyusutan bobot sebesar $0,35 \mathrm{~g}$ dan $0,68 \mathrm{~g}$ pada suhu $20^{\circ} \mathrm{C}$. Telur yang disimpan semakin lama maka semakin besar pula susut bobotnya. Telur yang disimpan selama 10 hari pada suhu $4^{\circ} \mathrm{C}$ memiliki penyusutan bobot sebesar $0,43 \mathrm{~g}$ dan meningkat pada penyimpanan 14 hari menjadi $0,56 \mathrm{~g}$.

Penurunan kualitas telur dapat terjadi seiiring dengan lamanya waktu penyimpanan. Semakin lama telur disimpan, maka semakin menurun pula kualitasnya. Penurunan kualitas telur yang dapat dilihat pada penelitian ini yaitu menurunnya nilai IKT sehingga mempengaruhi kadar lemak telur. Penurunan nilai IKT dan lemak telur ini menyebabkan penurunan pada bobot telur. 


\section{KESIMPULAN}

Perendaman telur dengan ekstrak daun salam dan penyimpanan pada suhu $4^{\circ} \mathrm{C}$ tidak mampu mempertahankan kualitas telur itik dilihat dari indeks kuning telur, kadar lemak telur, dan susut bobot telur.

\section{DAFTAR PUSTAKA}

Akyurek, H dan A. A. Okur. 2009. Effect of Storage Time, Temperature and Hen Age on Egg Quality in Free-Range Layer Hens. Journal of Animal and Veterinary Advances 8(10): 1953-1958.

Bintanah, S dan E. Handarsari. 2014. Komposisi Kimia dan Organoleptik Formula Nugget Berbasis Tepung Tempe dan Tepung Ricebran. Indonesian Journal of Human Nutrition 1(1): 57-70.

Budisutiya dan E. Arisandi. 2006. Penggunaan Babakan Kulit Kayu Bakau (Rhizophora mucronata Lamck) sebagai Pengawet Telur Ayam Ras. Jurnal Hutan Tropis Borneo 18: 39-53.

Chung, S. H and K. W. Lee. 2014. Effect of Hen Age, Storage Duration and Temperature on Egg Quality in Laying Hens. International Journal of Poultry Science 13(11):634-636.

Cornelia, M., C. C. Nurwitri dan Manissjah. 2005. Peranan Ekstrak Kasar Daun Salam (Syzygium Polyanthum Wight Walp.) dalam Menghambat Pertumbuhan Total Mikroba dan Echerichia coli pada Daging Ayam Segar. Jurnal Ilmu dan Teknologi Pangan 2(3): 35-45.

Cornelia, A., I. K. Suada dan M. D. Rudyanto. 2014. Perbedaan Daya Simpan Telur Ayam Ras yang dicelupkan dan tanpa dicelupkan Larutan Kulit Manggis. Indonesia Medicus Veterinus 3(2): 112-119.
Desmiaty, Y.; Ratih H.; Dewi M.A.; Agustin R. 2008. Penentuan Jumlah Tanin Total pada Daun Jati Belanda (Guazuma ulmifolia Lamk) dan Daun Sambang Darah (Excoecaria bicolor Hassk.) Secara Kolorimetri dengan Pereaksi Biru Prusia. Jurnal Ortocarpus. 8, 106-109.

Eke, M. O., N. I. Olaitan and J. H. Ochefu. 2013. Effect of Storage condition on the Quality Attributes of Shell (Table) Eggs. Nigerian Food Journal. NIFOJ, 2(31): 18-24.

Fibrianti, S. M., I. K. Suada dan M. D. Rudyanto. 2012. Kualitas Telur Ayam Konsumsi yang dibersihkan dan tanpa dibersihkan Selama Penyimpanan Suhu Kamar . Indonesia Medicus Veterinus 2012 1(3): 408- 416.

Finata, R. P., M. D. Rudyanto dan I. G. K Suarjana. 2015. Pengaruh Lama Penyimpanan pada Suhu Kamar Telur Itik Segar dan Telur yang Mengalami Pengasinan ditinjau dari Jumlah Eschericia coli. Buletin Veteriner Udayana 1 (7): 4147.

Gole, V.C., K. K. Chousalkar, J. R. Roberts, M. Sexton, D. May, J. Tan and A. Kiermeier. 2014. Effect of Egg Washing and Correlation between Eggshell Characteristics and EggPenetration by VariousSalmonella Typhimurium Strains. PLOS ONE 3(9): 1-12.

Hadjrawati., J.C. Likadja dan Hessy. 2012. Pengaruh Lama Perendaman Ekstrak Kulit Buah Kakao dan Lama Penyimpanan terhadap Daya Awet Telur Ayam Ras. Agriplus 1(22) ISSN 0854-0128.

Idayanti., S. Darmawati dan U. Nurullita. 2009. Perbedaan Variasi Lama Simpan Telur Ayam pada Penyimpanan Suhu Almari Es dengan Suhu Kamar terhadap Total Mikroba. Jurnal Kesehatan 1(2): 19-26. 
Indrawan, I. G., I. M. Sukada dan I. K. Suada. 2012. Kualitas Telur dan Pengetahuan Masyarakat tentang Penanganan Telur di Tingkat Rumah Tangga. Indonesia Medicus Veterinus 1(5): 607-620.

Jazil, N., A. Hintono, S. Mulyani.2012. Penurunan Kualitas Telur Ayam Ras dengan Intensitas Warna coklat kerabang berbeda selama penyimpanan.Jurnal Aplikasi Teknologi Pangan 1(2): 43-47.

Lestari, S., R. Malaka dan S. Garantjang. 2013. Pengawetan Telur dengan Perendaman Ekstrak Daun Melinjo (Gnetum gnemon L). Jurnal Sains dan Teknologi 2(13): 184-189.

Lubis, H. A., I. G. K. Suarjana dan M. D. Rudyanto. 2012. Pengaruh Suhu dan Lama Penyimpanan Telur Ayam Kampung terhadap Jumlah Escherichia Coli. Indonesia Medicus Veterinus 1(1) : 144 159.

Rahmawati, S., T. R. Setyawati dan A. H. Yanti. 2014. Daya Simpan dan Kualitas Telur Ayam Ras dilapisi Minyak Kelapa, Kapur Sirih dan Ekstrak Etanol Kelopak Rosella. Protobiont 1(3): 55-60.
Saraswati, T. R. 2015. Optimalisasi Fungsi Reproduksi Puyuh dan Biosintesis Kimiawi Bahan Pembentuk Telur. Leskonfi, Depok

Soeparno, R.A., I. Rihastutidan S. Triatmojo. 2011. Dasar Teknologi Hasil Ternak. Gadjah Mada University.Yogyakarta..

Sumono, A. dan Wulan A. 2009. Kemampuan air rebus daun salam (Eugenia polyantha w) dalam menurunkan jumlah koloni bakteri streptococcus sp. Majalah Farmasi Indonesia, 20 (3), 112-7.

Tarigan, R. L. $\mathrm{Br}$ dan K.K Agustina. 2016. Kualitas Telur Asin Bermedia Kulit Manggis (Garcinia Mangostana L) Berdasarkan Indeks Putih Telur, Kuning Telur, dan Haugh Unit. Indonesian Medicus Veterinus 5(1) : 30-37.

Yuwanta, T. 2010. Telur dan Kualitas Telur. Gadjah Mada University Press, Yogyakarta. 